\title{
The use of green energy for energy conservation in high-rise buildings
}

\author{
Nikolay Rudenko ${ }^{1, *}$, Valery Ershov ${ }^{1}$ \\ ${ }^{1}$ Don State Technical University, 1, Gagarin Square, 344000, Rostov-on-Don, Russia
}

\begin{abstract}
The article discusses technical proposals for energy saving in high-rise buildings based on the use of "green" energy. These include: the use of hybrid wind and solar power plants and vortex wind-driven power plants with a vertical axis to utilize both the energy of horizontal wind flows at height level and the energy of ascending airflows. The general principles of building hybrid wind and solar power plants for energy conservation in high-rise buildings are set forth based on the analysis of prior art. These include the following: to ensure safe operation and the absence of tele-interruptions, it is advisable to close the wind turbines with a dome design that has a cavity that captures the wind flow; to ensure environmental friendliness and ease of management, it is advisable to use a variety of vertical vortex wind turbines of modular design; for efficient use of solar energy, it is advisable to integrate photovoltaic cells into the outer structure of the dome; To reduce the cost of the project, it is advisable to use the existing high-rise buildings. A vortex wind power installation is proposed, which allows the use of small winds and low-potential thermal flows, to reduce low-frequency vibration, to increase the stability and efficiency of use of wind energy with ease of installation, maintenance and repair.
\end{abstract}

\section{Introduction}

An important component of energy conservation is the construction of energy-efficient buildings using environmentally friendly alternative energy. Since the cost of land for construction in all the urban centers, high-rise construction is used. Thus, the main part of the housing stock in Moscow is represented by 16-22-story buildings. The total number of such buildings is more than 4.500 [1]. However, research and methodological bases of energy conservation in high-rise buildings based on green energy have not been yet developed.

Therefore, development of science-based technical proposals on energy conservation in high-rise buildings based on environmentally friendly renewable energy sources is most pressing technical task.

\footnotetext{
* Corresponding author: doptaganka@yandex.ru
} 


\section{Materials and methods}

The task may be formulated as follows: To draft technical proposals on energy conservation in high-rise buildings based on environmentally friendly renewable energy sources.

To solve the task, it is necessary to study and work out the following issues:

- choice renewable energy sources for energy conservation in high-rise buildings:

- elaboration of proposals on environmental properties of energy sources;

- justification for the efficient utilization of the chosen energy sources;

- analysis of prior art:

- elaboration of technical recommendations on the plants to be designed.

\subsection{Choice renewable energy sources}

It would be feasible to choose then in view of specific geographic region. The review of renewable energy sources in Russia suggests the following conclusions:

- zones of effective use of wind-driven power plants in the constituent territories of the Russian Federation are: the oblasts (or regions) of Arkhangelsk, Astrakhan, Volgograd, Kaliningrad, Kamchatka, Leningrad, Magadan, Murmansk, Novosibirsk, Rostov and Tyumen; the krais (or territories) of Krasnodar, Perm, Primorsky and Khabarovsk; the republics of Dagestan, Kalmykia, Khakassia and Sakha (Yakutia); and the autonomous districts of Nenets, Chukotka and Yamalo-Nenets [2, 3];

- the most promising zones in terms of using solar panels: Kalmykia, Stavropol Krai, Rostov Oblast, Krasnodar Krai, Volgograd Oblast, Astrakhan Oblast and other regions in the southwest, Altai, Primorye, Chita Oblast, Buryatia and other regions of Western and Eastern Siberia and the Far East [2, 3];

- hybrid wind and solar power plants which combine solar panels and wind generators are the most popular. They successfully replace low-power gas turbines, fuel oil boilers, and diesel generators, especially those located in the zone of distributed power generation. Their use can increase the share of renewable sources in electricity production from $5 \%$ to $15 \%$ by $2035[4,5]$.

Consequently, concurrent use of various kinds of alternative energy, such as wind and solar energy is most effective. All they together in a complementary manner guarantee generation of sufficient amount of energy.

Thus, to provide energy conservation in high-rise buildings it is appropriate to utilize hybrid wind and solar power plants, as they use all advantages and make up all disadvantages of individual sources.

\subsection{Elaboration of proposals on ensuring environmental properties of energy sources}

To formulate such proposals, it is advisable to review the environmental properties of the elements of hybrid wind and solar power plants: wind-driven power plants and solar power plants.

The environmental properties of the wind-driven power plants can be improved by the use of wind turbines with a vertical axis. They have the following advantages $[6,7,8]$ :

- reduced initial rotation speed (from $1.3 \mathrm{~m} / \mathrm{s}$ );

- no vibration to the ground;

- no need to install high poles;

-environmental friendliness (noise level does not exceed $35 \mathrm{~dB}$ );

- no need to trace a wind direction;

- utilization of not only horizontal, but ascending wind flows as well. 
The environmental issues associated with the use of solar power plants are currently being successfully addressed by using environmentally friendly technologies for the production and disposal of solar panels containing cadmium telluride [9].

Thus, proposals on ensuring the environmental properties of energy sources can be formulated as follows:

- to use wind turbines with a vertical axis;

- to use environmentally friendly technologies for the production and disposal of solar panels.

\subsection{Justification for the efficient utilization of the chosen energy sources}

A number of studies $[10,11]$ show that the use of solar and wind energy in buildings makes it possible to save up from $11 \%$ to $15 \%$ in energy consumption per year. In our country the pattern when the energy from renewable energy sources is converted into heat and hot water has proved to be the most popular and economically viable one. This pattern has several advantages [11]:

- heating is the main energy-consuming item at any house in Russia;

- the pattern consisting of wind turbines and automatic control system becomes much less complicated;

- the simplest automatic control system can incorporate only few thermal breakers;

- a common water boiler for heating and hot water supply may be used as an energy storage device;

- the heating system consumes less energy; - a room temperature can be maintained within a broad range from 19 to $25^{\circ} \mathrm{C}$, and a temperature in hot-water supply boilers within a range from 40 to $60{ }^{\circ} \mathrm{C}$ without adversely affecting the consumers.

In addition, it is well known that in the cold and warm period of the year the wind velocity increases depending on height [12]. To estimate the relationship between wind velocity and height, various models are used, such as the Ekman spiral, logarithmic law, and power law $[12,13,14]$. These models make it possible to estimate wind velocity $v$ at height $h$, when wind velocity $v_{0}$ at height $h_{0}$ is known. For example, the power law wind velocity change as a function of height is $[12,13,14]$ :

$$
V_{h}=V_{0} \cdot\left(\frac{h}{h_{0}}\right)^{a},
$$

where $V_{h}$ - wind velocity, $\mathrm{m} / \mathrm{s}$, at a height $h, \mathrm{~m}$;

$V_{0}$ - wind velocity, $\mathrm{m} / \mathrm{s}$ measured at a height $h_{0}, \mathrm{~m}$ (as a rule, wind velocities are measured at a height of $10-15 \mathrm{~m}$, and in this case $h_{0}=10-15 \mathrm{~m}$ );

$a$-index of a power which depends on the type of terrain and is established experimentally; in [12] for major city centers it is recommended to take a $=0,33$.

We obtain the dependence of the wind velocity at a height of 50 meters (approximately the roof level of a 16-story building) on the wind velocity at a height of 10 meters, taking into consideration the ratio (1). To that end, we substitute the indicated height values in the formula to obtain the linear dependency (function)

$$
V_{50}=5^{0,33} \cdot V_{10} \approx 1,7 \cdot V_{10},
$$

where $V_{50}$ - wind velocity, $\mathrm{m} / \mathrm{s}$, at a height of $50 \mathrm{~m}$; 
$V_{10}$ - wind velocity, $\mathrm{m} / \mathrm{s}$, at a height of $10 \mathrm{~m}$.

The graph of the dependency is presented in Figure 1 that clearly shows that starting with a wind velocity of $3 \mathrm{~m} / \mathrm{s}$ at a height of $10 \mathrm{~m}$ at a height of $50 \mathrm{~m}$, the wind velocity will be higher than $5 \mathrm{~m} / \mathrm{s}$, which is the boundary of the zone of effective use of wind-driven power plants $[2,3]$.

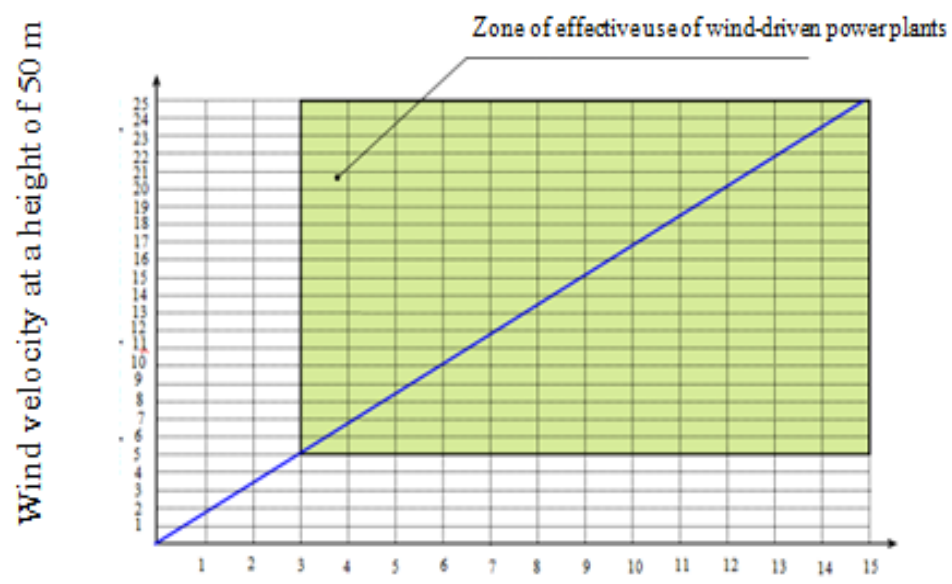

Wind velocity at a height of $10 \mathrm{~m}$

Fig. 1. Dependence of the wind velocity at a height of 50 meters (approximately the roof level of a 16 -story building) on the wind velocity at a height of 10 meters.

Thus, the use of wind-driven power plants installed at roofs of high-rise (more than 16story) buildings is economically efficient even at wind velocity $3 \mathrm{~m} / \mathrm{s}$ at a height of $10 \mathrm{~m}$.

In addition, on sunny days during the warm season the outer surfaces of buildings are exposed to solar radiation, as a result of which their temperature increases dramatically and differs significantly from the ambient temperature. The temperature difference produces a convective heat flux directed upwards the building, and the so-called near-surface (boundary) layer of heated air appears. An example of the velocity profile of the ascending air flows at the outer surface of a high-rise building as a result of the temperature difference $D t=20^{\circ} \mathrm{C}$ is shown in Figure 2 [14]. 


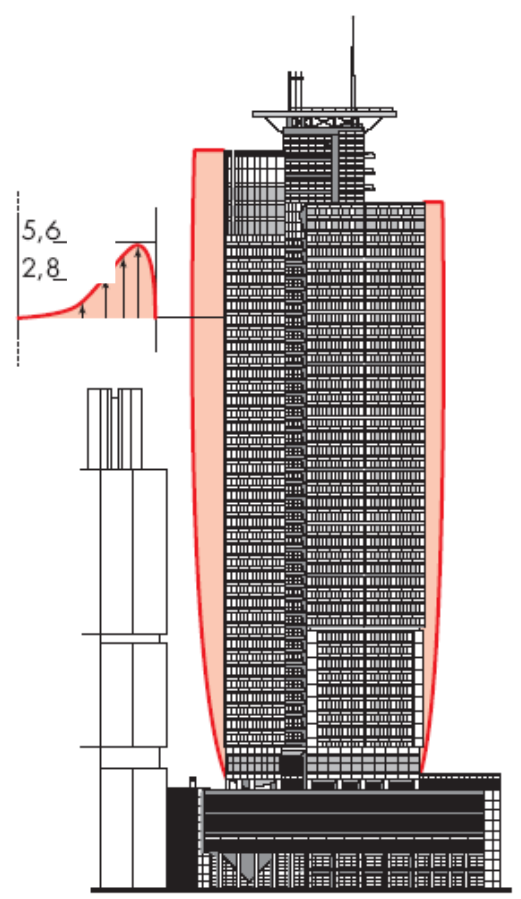

Fig. 2. Example of the velocity profile of the ascending air flows at the outer surface surface of a high-rise building as a result of the temperature difference $\Delta t=20^{\circ} \mathrm{C}$.

The graphs (Fig. 3) show the dependency of the air flow velocity at the outer surface of the building established by foreign researchers [13].

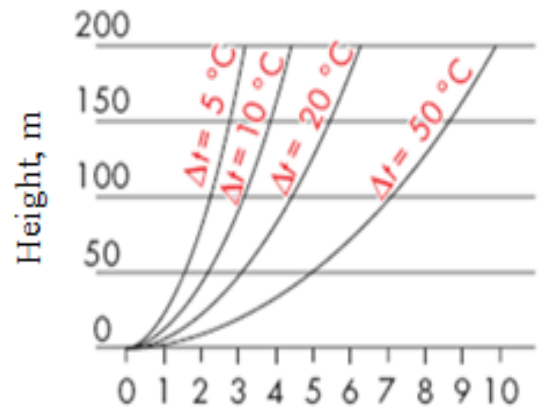

\section{Maximum velocity of ascending air flows, $\mathrm{m} / \mathrm{s}$}

Fig. 3. Dependency of air flow velocity at the outer surfaces of the building on height and temperature difference.

From Figures 2 and 3 it is obvious that the ascending air flows at a height of more than $50 \mathrm{~m}$ can have a velocity of 2 to $5 \mathrm{~m} / \mathrm{s}$. The energy of these air flows can be used by vortex wind-driven power plants.

Thus, to ensure energy conservation in high-rise buildings it would be feasible to use vortex wind-driven power plants with a vertical axis to utilize both the energy of horizontal wind flows at height and the energy of ascending air flows. 


\subsection{Analysis of prior art}

Some studies $[10,15-18]$ contain analysis of experience in the use renewable energy sources to provide energy efficiency and classification of wind-driven power plants on top of buildings. Let's consider some of such prior art presented in Fig. 4 [17, 18].

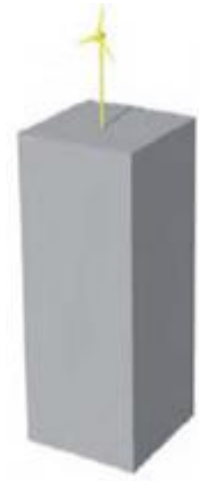

a)

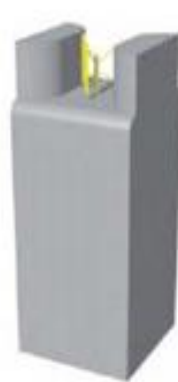

b)

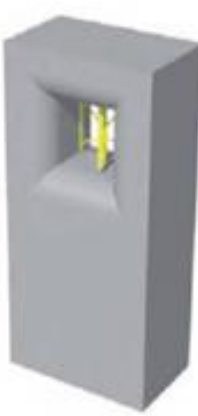

c)

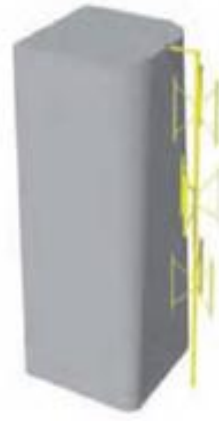

d)

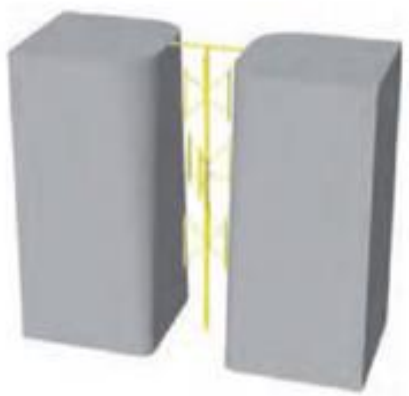

e)

Fig. 4. Options of prior use of the wind-driven power plants on top of buildings:a) the first option is to place a wind turbine with a horizontal rotation axis in the upper part of a high-rise building; b) the second option is to place a wind turbine with a vertical rotation axis in the upper part of a high-rise building; c) the third option is to confine a wind turbine in a building; d) the fourth option is to mount wind turbines to the side of a building; e) the fifth option is to install wind turbines between buildings, Source: http:// www. energo.house/veter/zdanie-s-vetrovoj-energiej.html.

The most interesting option is the project of high-rise building CleanTechnologyTower (Chicago, USA) (sixth option) based on the concept of "biomimicry"; that is to say, on the most advanced systems of sustainable development. The unique tower envelope has symbiotic relationship with the environment (Fig. 5). Wind turbines at the building's corners capture wind at its highest velocity as it accelerates around the tower. The turbines become denser as the tower ascends and wind speeds increase. At the tower's apex, where wind speeds are highest, a domed double roof cavity captures air, creating a large wind farm; negative pressures ventilate the interior. The dome is shaded by photovoltaic cells that capture the southern sun [19]. 


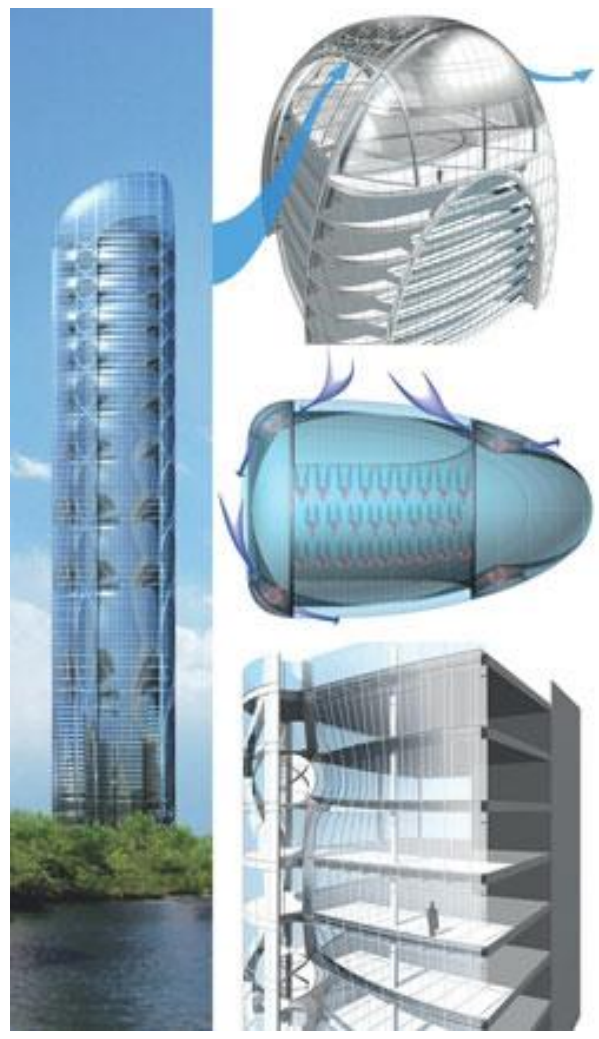

Fig. 5. Project of Clean Technology Tower (Chicago, USA), Source: http://smithgill.com/work/clean _technology_tower_1/.

To analyze these 6 options, it is advisable to apply the following evaluation criteria listed in an order of importance in view of urban conditions:

a) operational safety;

b) environmental friendliness (low level of vibration and noise);

c) cost of construction, installation, operation and repair;

d) possibility of installation in existing buildings;

e) effective use of wind and solar energy;

f) easy control;

g) television interference.

The results of the analysis of 6 options against the above criteria are presented in table 1 .

Table 1. Characteristics of the options of the use of wind-driven power plants installed on top of buildings.

\begin{tabular}{|c|c|c|c|c|c|c|c|}
\hline \multirow{2}{*}{$\begin{array}{c}\text { № } \\
\text { of } \\
\text { optio } \\
\text { n }\end{array}$} & \multicolumn{7}{|c|}{ Evaluation criteria } \\
\hline & $\begin{array}{c}\text { Operatio } \\
\text { nal } \\
\text { safety }\end{array}$ & $\begin{array}{c}\text { Environmen } \\
\text { tal } \\
\text { friendliness }\end{array}$ & $\begin{array}{c}\begin{array}{c}\text { Cost } \\
\text { of }\end{array} \\
\text { constructi } \\
\text { on, } \\
\text { installatio } \\
\text { n, } \\
\text { operation } \\
\text { and } \\
\text { repair }\end{array}$ & $\begin{array}{c}\text { Possibilit } \\
\text { y of } \\
\text { installati } \\
\text { on in } \\
\text { existing } \\
\text { buildings }\end{array}$ & $\begin{array}{c}\text { Effective } \\
\text { use of } \\
\text { wind and } \\
\text { solar } \\
\text { energy; }\end{array}$ & $\begin{array}{c}\text { Easy } \\
\text { control }\end{array}$ & $\begin{array}{c}\text { Television } \\
\text { interferen } \\
\text { ce }\end{array}$ \\
\hline 1 & Low No & Low & High due to & Yes & High & Low 1 & High \\
\hline
\end{tabular}




\begin{tabular}{|c|c|c|c|c|c|c|c|}
\hline & envelope & $\begin{array}{l}\text { Horizontal } \\
\text { wind-driven } \\
\text { power plant } \\
\text { is used }\end{array}$ & $\begin{array}{l}\text { the high } \\
\text { installation } \\
\text { costs }\end{array}$ & & & $\begin{array}{l}\text { powerf } \\
\text { ul wind } \\
\text { turbine }\end{array}$ & $\begin{array}{l}\text { Blade } \\
\text { wind- } \\
\text { driven } \\
\text { power } \\
\text { plants } \\
\text { cause } \\
\text { television } \\
\text { interferenc } \\
\text { e [20] }\end{array}$ \\
\hline 2 & $\begin{array}{l}\text { Low No } \\
\text { envelope }\end{array}$ & $\begin{array}{l}\text { High } \\
\text { Vertical } \\
\text { wind-driven } \\
\text { power plant } \\
\text { is used }\end{array}$ & $\begin{array}{l}\text { High An } \\
\text { additional } \\
\text { architectura } \\
1 \text { project is } \\
\text { required }\end{array}$ & No & $\begin{array}{l}\text { High } \\
\text { The shape } \\
\text { of the } \\
\text { building } \\
\text { stimulates } \\
\text { the } \\
\text { movement } \\
\text { of air and } \\
\text { turbine }\end{array}$ & $\begin{array}{l}\text { Low 1 } \\
\text { powerf } \\
\text { ul wind } \\
\text { turbine }\end{array}$ & High \\
\hline 3 & $\begin{array}{l}\text { Low No } \\
\text { envelope }\end{array}$ & $\begin{array}{l}\text { High } \\
\text { Vertical } \\
\text { wind-driven } \\
\text { power plant } \\
\text { is used }\end{array}$ & $\begin{array}{l}\text { High An } \\
\text { additional } \\
\text { architectura } \\
1 \text { project is } \\
\text { required }\end{array}$ & No & $\begin{array}{l}\text { High The } \\
\text { facade } \\
\text { design } \\
\text { (relief) } \\
\text { enhances } \\
\text { and } \\
\text { directs the } \\
\text { wind } \\
\text { flows to } \\
\text { wind- } \\
\text { driven } \\
\text { power } \\
\text { plants. }\end{array}$ & $\begin{array}{l}\text { Low 1 } \\
\text { powerf } \\
\text { ul wind } \\
\text { turbine }\end{array}$ & High \\
\hline$\overline{4}$ & $\begin{array}{l}\text { Low No } \\
\text { envelope }\end{array}$ & $\begin{array}{l}\text { High } \\
\text { Vertical } \\
\text { wind-driven } \\
\text { power plants } \\
\text { are used }\end{array}$ & $\begin{array}{l}\text { High An } \\
\text { additional } \\
\text { architectura } \\
1 \text { project is } \\
\text { required }\end{array}$ & No & $\begin{array}{l}\text { High The } \\
\text { shape of } \\
\text { the } \\
\text { building } \\
\text { stimulates } \\
\text { the } \\
\text { movement } \\
\text { of air and } \\
\text { turbine }\end{array}$ & $\begin{array}{l}\text { High } \\
\text { Many } \\
\text { small- } \\
\text { sized } \\
\text { wind } \\
\text { turbine } \\
\text { s }\end{array}$ & High \\
\hline 5 & $\begin{array}{l}\text { Low No } \\
\text { envelope }\end{array}$ & $\begin{array}{l}\text { High } \\
\text { Vertical } \\
\text { wind-driven } \\
\text { power plants } \\
\text { are used }\end{array}$ & $\begin{array}{l}\text { High An } \\
\text { additional } \\
\text { architectura } \\
1 \text { project is } \\
\text { required }\end{array}$ & No & $\begin{array}{l}\text { High The } \\
\text { shape of } \\
\text { the } \\
\text { building } \\
\text { stimulates } \\
\text { the } \\
\text { movement } \\
\text { of air and } \\
\text { turbine }\end{array}$ & $\begin{array}{l}\text { High } \\
\text { Many } \\
\text { small- } \\
\text { sized } \\
\text { wind } \\
\text { turbine } \\
\text { s }\end{array}$ & High \\
\hline 6 & $\begin{array}{l}\text { High The } \\
\text { protective } \\
\text { dome is } \\
\text { available }\end{array}$ & $\begin{array}{l}\text { High } \\
\text { Vertical } \\
\text { wind-driven } \\
\text { power plants } \\
\text { are used }\end{array}$ & $\begin{array}{l}\text { High An } \\
\text { additional } \\
\text { architectura } \\
1 \text { project is } \\
\text { required }\end{array}$ & Yes & $\begin{array}{l}\text { High A } \\
\text { domed } \\
\text { double } \\
\text { roof } \\
\text { cavity } \\
\text { captures } \\
\text { air. The } \\
\text { dome is }\end{array}$ & $\begin{array}{l}\text { High } \\
\text { Many } \\
\text { small- } \\
\text { sized } \\
\text { wind } \\
\text { turbine } \\
\text { s }\end{array}$ & $\begin{array}{l}\text { Absent } \\
\text { due to the } \\
\text { shaded } \\
\text { dome. }\end{array}$ \\
\hline
\end{tabular}




\begin{tabular}{|l|l|l|l|l|l|l|}
\hline & & & $\begin{array}{l}\text { shaded by } \\
\text { photovolt } \\
\text { aic } \\
\text { cells[19] }\end{array}$ & \\
\hline
\end{tabular}

\section{Results and discussion}

Elaboration of technical recommendations on the plants to be designed. Based on the above principles, the Don State Technical University (Rostov-on-Don, Russia) developed a useful model of a vortex wind turbine [21], as well as the invention of a vortex wind turbine [22], which can be used for energy saving in high-rise buildings on larger parts of the territory of Russia, where the average annual wind speed is in the range of $3-4.5 \mathrm{~m} / \mathrm{s}$. The proposed vortex wind turbines has the following advantages [10, 15, 20-22]:

- low noise and vibration (less than $35 \mathrm{~dB}$ ), which enables to place it on roofs of the buildings related to industrial complexes, which makes it possible to use not only the energy of horizontal wind currents, but also the energy of vertical rising air currents during ventilation of the industrial building

- no necessity to construct a separate high-rise structure in the form of mast for vortex wind turbine with a height of at least 30 - 40 meters for ensuring the required wind velocity;

- fast speed and ease of installation, maintenance and repair, since the plant is located on the building roof at the plant base, instead of a high-rise mast;

- the possibility of using weak wind and low-potential thermal rising air currents enables to obtain reduced initial rotation velocity (from $1.3 \mathrm{~m} / \mathrm{s}$ );

- increased stability of all structures of the vortex wind turbine, since the generator and, consequently, the plant center of inertia are located at the vortex wind turbine base;

- simplification of operation technology through extending the service life of bearing assemblies;

- improving the efficiency of using wind energy.

\subsection{Design of the vortex wind-driven power plant (the invention)}

This design is presented in Fig. 6 [22]. Wind-driven power plant comprises the flare fitting 5 made in the form of a truncated cone or cylinder that transits into a truncated cone, and a rotor located in it along its vertical axis, made in the form of shaft 2 with a conical screw blade 3 fastened on it. And the blades 7 are fixed by means of connecting disks 6 below it on the shaft 2 . The blades are partially protruded 8 from the lower part of the flare fitting 5 . The flare fitting 5 is mounted on the supports 9 with the axial bearings 14 (at least three in terms of stability conditions). The power crosspiece 4 which is rigidly connected to the flare fitting 5 is located at the level of the upper edge 16 of the flare fitting 5 in the horizontal plane. The center of this crosspiece contains the bearing assembly 1 which is fixed to the shaft 2 of the rotor with the possibility of rotation. The power crosspiece 11, the center of which contains the bearing assembly 13, in which the shaft 2 of the rotor is fixed with the possibility of rotation, is mounted at the level of the lower part of the supports 9 of the flare fitting 5 in the horizontal plane. The crosspiece 11 is rigidly connected to the supports 9 through the power elements of the structure 12. The Electromotive Force generator 10 is mounted on the power crosspiece 11 at the lower parts of supports 9 of the flare fitting 5 in the horizontal plane. Rotor of the Electromotive Force generator 10 is rigidly connected to the shaft 2 of rotor. Dimensions of the rotor in the Electromotive Force generator 10 are conditioned by the possibility to generate the maximum possible EMF and are limited to the supports 9 of the flare fitting 5. Flare fitting 5 has a lower edge 15. 


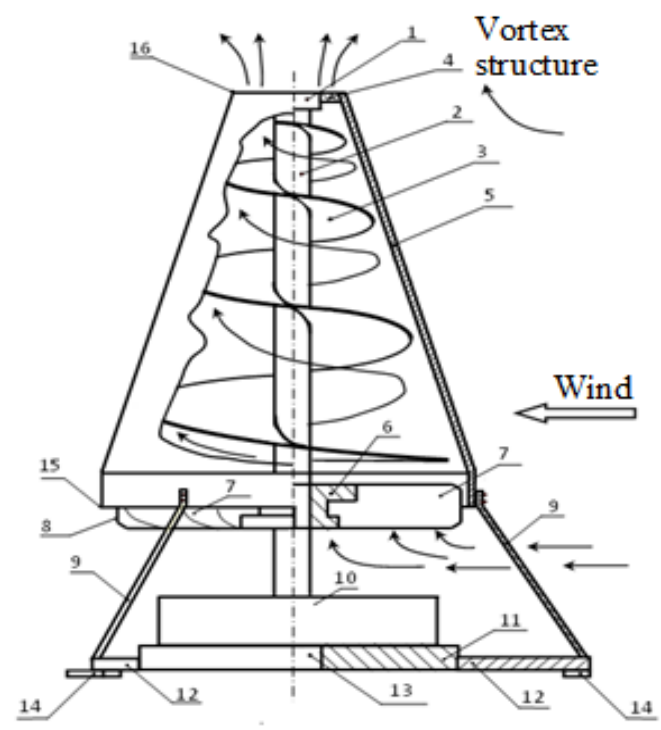

Fig. 6. Design of the vortex wind-driven power plant.

\subsection{The essence of an invention}

The essence of an invention is that the wind power plant containing a bell made in the form of a truncated cone or cylinder turning into a truncated cone, and a rotor located in it along its vertical axis, made in the form of a shaft with a conical screw blade fixed to it, and below it on the shaft blades are fixed by means of connecting disks with a partial protrusion of them from the lower part of the bell [22]. The bell is mounted on at least three supports with thrust bearings, according to stability conditions, at the level of the upper cut of the bell in a horizontal plane there is a power crosspiece fixedly rigidly connected to the bell, in the center of which there is a bearing assembly, in which the rotor shaft is mounted rotatably. The EMF generator is mounted on the power crosspiece at the level of the lower part of the supports of the bell in a horizontal plane, the rotor of the EMF generator is rigidly connected to the rotor shaft, and the conical helical blade with a variable radius decreasing in the direction from the lower to the upper cut of the bell is fastened on the shaft inside the bell on the blades with partial protrusion of them from the lower part of the bell.

The process of the whole energy utilization of the vortex flow in the bell is as follows. With the beginning of the rotor rotation and the resulting air circulation in the direction from the lower to the upper cut of the bell, there is an increase of pressure on the conical screw blade.

The force of the wind flow $\bar{F}_{W F}$ due to the increase of pressure (Fig. 7), is applied to the lower surface of the conical screw blade. At the point of application of force $\overline{\mathrm{F}}_{\mathrm{WF}}$ to the blade, two forces arise in it in a vertical plane. The first one is directed normal to the plane of the blade $\bar{F}_{N}$ and the second one is the tangential force $\bar{F}_{T}$ directed tangentially to the edge of the blade and in the direction coinciding with the direction of the edge of the conical screw blade. 


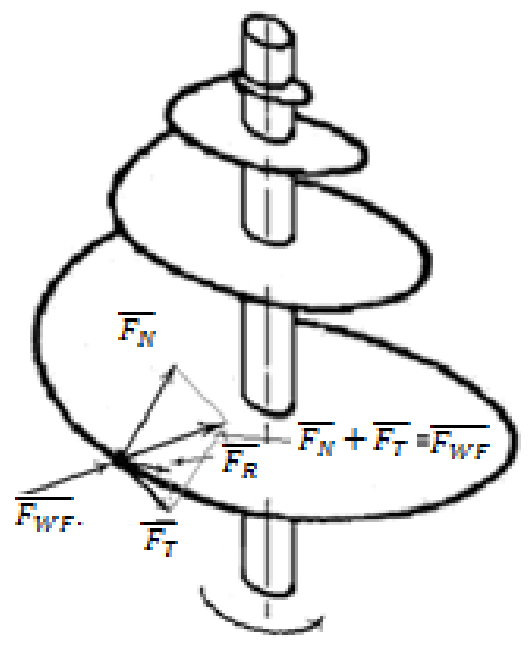

Fig. 7. Axonometric projection of a conical screw blade and the forces acting on it.

The resultant of these forces $\bar{F}_{N}$ and $\bar{F}_{T}$ representing the diagonal of the rectangle formed by these forces, as on the sides of the rectangle, is generated by the force of the wind flow $\bar{F}_{W F}$ and is equal to it in magnitude, i.e.

$$
\bar{F}_{N}+\bar{F}_{T}=\bar{F}_{W F}
$$

The projection of the force $\bar{F}_{T}$ onto a horizontal plane, that is perpendicular to the axis of rotation of the shaft of the wind turbine and that passes through the point of force application $\bar{F}_{W F}$, represents the rotation force $\bar{F}_{R}$.

Thus, as a result of the pressure of the vortex flow on the conical screw blade in the mouth, the work of the rotation force $\bar{F}_{R}$ occurs, which creates a useful capacity creep on the shaft of the wind power plant.

The improvement of the efficiency of wind energy usage can be shown as follows.

We can evaluate the components included in the equations characterized the balance of their power, assuming that the power of the wind flow $\mathrm{P}_{\mathrm{WF}}$, applied to the device of the patent [21] and to the proposed device are the same.

The power of the air flow applied to the device according to the patent [21]:

$$
P_{W F}=P_{B P P}+P_{U}+\Delta P_{L \cdot B P P}
$$

where $P_{\mathrm{BPP}}$ is the power generated on the shaft by the blades with a partial protrusion of them from the lower part of the bell;

$P_{U}$ is the unused power of the vortex flow in the bell behind the blades with the partial protrusion of them from the lower part of the bell;

$\triangle P_{L . B P P}$ is the power friction losses in bearings and friction of the air flow on the blades with partial protrusion of them from the lower part of the bell.

In the equation (3), the $P_{\mathrm{U}}$ component in relation to the proposed device is presented in the form:

$$
P_{N}=P_{C S B}+\Delta P_{L . C S B}+P_{U}^{\prime}
$$

where $P_{\mathrm{CSB}}$ is the power created on the shaft by a conical screw blade;

$\Delta P_{\mathrm{L} . \mathrm{CSB}}$ is the power friction losses in bearings and friction of the air flow on a conical helical blade; 
$P_{\mathrm{U}}^{\prime}$ is the unused power of the vortex flow in the bell behind the conical screw blade.

The power of the air flow applied to the proposed device is next [22]:

$$
P_{W F}=P_{B P P}+\Delta P_{L . B P P}+P_{C S B}+\Delta P_{L . C S B}+P_{U}^{\prime}
$$

where $P_{\mathrm{BPP}}$ is the power generated on the shaft by the blades with a partial protrusion of them from the lower part of the bell;

$\triangle P_{L . B P P}$ is the power friction losses in bearings and friction of the air flow on the blades with partial protrusion of them from the lower part of the bell.

$P_{C S B}$ is the power created on the shaft by a conical screw blade which arises due to the use of vortex flow energy in the bell;

$\Delta P_{L . C S B}$ is the power friction losses in bearings and friction of the air flow on a conical helical blade;

$P^{\prime}{ }_{U}$ is the unused power of the vortex flow in the bell behind the conical screw blade.

It follows on the comparison of equations (3) and (5), that the unused power of the vortex flow $P_{U}$ in equation (3) of the proposed device, as shown in equations (4), is the sum of the power generated on the shaft by a conical helical blade $P_{\mathrm{CSB}}$, power friction losses in bearings and friction of the air flow on a conical helical blade $\Delta P_{\mathrm{L} . \mathrm{CSB}}$ and the unused power of the vortex flow in the bell behind the conical screw blade $P^{\prime} \mathrm{U}$.

The unused power of the vortex flow in the bell in the proposed device is less than that in the patent [19], i.e. $P^{\prime}{ }_{\mathrm{U}}$ is less than $P_{\mathrm{U}}$; and friction losses in both cases are comparable.

Then the efficiency of the devices for the patent [21] and the present invention [21] respectively, are:

$$
\begin{aligned}
& \eta_{1}=P_{\mathrm{BPP}} / P_{\mathrm{WF}} \\
& \eta_{2}=\left(P_{\mathrm{BPP}}+P_{\mathrm{CBS}}\right) / P_{\mathrm{WF}}
\end{aligned}
$$
higher.

It follows on the equations (6) and (7), that the efficiency in the proposed device is

Thus, fixing a conical helical blade with a variable radius on the shaft of the wind power plant, decreasing in the direction from the lower to the upper cut of the socket, allows to obtain an increase in power on the shaft due to the power created by the conical screw blade, which arises due to the use of the vortex flow energy in the socket, and on this basis, with the same value of the air flow power as in the prototype, to increase the efficiency in the proposed wind power installation.

\subsection{Operation of the vortex wind-driven power plant}

When the wind blows-off the protrusion of blades 7 of rotor, the shaft 2 of rotor starts to rotate, causing a difference in the velocities of the air layers in the space between the lower 15 and the upper 16 edges of the flare fitting 5 due to formation of a vortex current according to Bernoulli differential equation, thus causing generation of stable vortex air current which ensures conversion of wind energy into mechanical energy of rotation of the wind wheel containing the disks 6 and the blades 7, and the shaft 2 of rotor (Fig. 6) [22].

The air current emerging in the flare fitting 5 affects the conical screw blade 3 . This action generates the force that acts on the conical screw blade 3 from the side of the air current flowing through it. The power which is generated by this force is proportional to the product of the mass momentum of the air passing through the conical screw blade 3 per time unit by the velocity difference before and after it. This force causes the emerging of additional torque which is generated by the conical screw blade 3, ensuring an increase in the efficiency of wind energy utilization. 
Thus, fixing the conical screw blade 3 with a variable radius which decreases in the direction from the lower 15 to the upper 16 edge of the flare fitting 5 on the wind-driven power plant shaft 2 enables to obtain capacity creep on the shaft 2 owing to the power generated by the conical screw blade 3, which emerges owing to the use of vortex current energy in the flare fitting 5 , and on this basis - to increase the efficiency in the proposed wind-driven power plant with the same value of the air current power as in the prototype.

\section{Conclusion}

1. The analysis of opportunities of renewable energy sources has shown that to ensure energy conservation in high-rise buildings it is feasible to use hybrid wind and solar power plants.

2. The following proposals on ensuring the environmental properties of energy sources are formulated: too use wind turbines with a vertical axis; to use environmentally friendly technologies for the production and disposal of solar panels.

3. In Russia the pattern when the energy from renewable energy sources is converted into heat and hot water has proved to be the most popular and economically viable one.

4. Analysis of wind speed and air movement near high-rise buildings allows us to draw the following conclusions:

- for energy saving in high-rise buildings, it is advisable to use vortex wind turbines with a vertical axis, which allow you to use both the energy of horizontal wind flows at a height and the energy of ascending air flows;

- the use of vortex wind turbines by installing them on the roof of tall buildings (above 16 floors) is economically effective already at a speed of $3 \mathrm{~m} / \mathrm{s}$ at a height of $10 \mathrm{~m}$.

5. The analysis of known technical solutions allows us to formulate the following general principles for constructing hybrid solar-wind power plants for energy conservation in highrise buildings:

- to ensure safe operation and the absence of television interference, it is advisable to cover the wind turbines with a dome having a double roof cavity that captures air (wind flow);

- to ensure environmental friendliness and easy control it is advisable to use a variety of vortex wind-driven power plants in a modular design;

- to guarantee efficient use of solar energy, it is advisable to shade the dome by photovoltaic cells;

- to reduce the cost of the project it is advisable to use the existing high-rise buildings.

6. A vortex wind turbine has been proposed and patented, which allows the use of small winds and low-potential thermal ascending flows, reduce low-frequency vibration, increase the stability and efficiency of use of wind energy with ease of installation, maintenance and repair.

\section{References}

1. T.V. Pogoreltseva, The Moscow Housing Stock in Figures. How Many Buildings Are in the Capital? Portal "Real Estate Market Indicators", http://www.irn.ru/articles/8489.html

2. P. Bezrukikh, Wind power (Publishing House "Energy", Moscow, 2010)

3. Resources and Efficiency of Use of Renewable Energy Sources in Russia. Group of authors (Nauka, St. Petersburg, 2002)

4. N.V. Rudenko, A.G.Sukiyazov, Yu.A. Shokova, 7th International Scientific Conference Science and Society (ISPC), 43-50 (2014) 
5. N.V. Rudenko, V.V. Ershov, V.V. Evstafiev, IOP Conf. Series: Earthand Environmental Science 66 (1) (2017)

6. N.V. Rudenko et al., Scientific almanah 7 (9), 790-801 (2015) doi: 10.17117/na.2015.07.790

7. N.V. Rudenko, V.V. Ershov, V.V. Evstafiev, International Conf. on Industrial Eng., Application. and Manufact. (ICIEAM) (2017) doi: 10.1109/ICIEAM.2017.8076240

8. W.T. Chong et al., Journal of Central South University 19(3), 727-732 (2012)

9. W.X. Shen, Optimally sizing of solar array and battery in a standalone photovoltaic system in Malaysia. Renewable Energ, 34(1), 348-352 (2009)

10. Wind-Driven Generator in Heaven. Analytical Portal of the Chemical Industry, http://www.newchemistry.ru/letter.php?n_id=6249

11. V.K. Averyanov et al., Energy Conservation 6, 68-73 (2015)

12. ASHRAE, Handbook. Fundamentals (SI Edition, 1997)

13. A. Mottaeva, A. Zheltenkov, E3S Web of Conferences, 33, 01038 (2018) doi: $10.1051 / \mathrm{e} 3$ sconf $/ 20183301038$

14. Yu.A. Tabunshchikov, N.V. Shilkin, ACADEMIA. Architecture and Construction 2, 81-85 (2007)

15. N.V. Rudenko, V.V. Ershov, N.A. Konshina, IOP Conf. Series: Earth and Environmental Science 224 (1) (2019)

16. V.V. Elistratov, D.M. Bobrova, Wind-Driven Power Plants - Architectural Element of Building, Architecture and Modern Information Technologies. Electronic journal, http://www.marhi.ru/AMIT/2013/2kvart13/bobrova_elistratov/bobrova_elistratov.pdf

17. A.M. Generalov, The Role of Facade Systems in the Struggle for Energy Efficiency, Association of HVAC Engineers, 8, 48-53 (2017)

18. O. A. Pomine, Top-5 of versatile multi-functional buildings with wind power: unusual use of wind turbines in modern architecture. Portal "Energy-saving technologies". Available at: http:// www. energo.house/veter/zdanie-s-vetrovoj-energiej.html (accessed: February 19, 2020)

19. Clean Technology Tower (Chicago, USA). Available at: http://smithgill.com/work/clean_technology_tower_1/ (accessed: February 19, 2020).

20. R.A. Serebryakov, V.V. Biryuk, Vortex wind-driven power plant, Alternative Energy and Ecology, 7, 27-30 (2013)

21. N. Rudenko, V. Ershov, I. Pugachev, Device for converting kinetic wind energy into mechanical energy: utility model patent No. 182523 Russian Federation. No. 2018104927 Bull. Number 24 (2018)

22. N. Rudenko, V. Ershov, I. Pugachev, N. Konshina, Wind power plant: patent for invention No. 2689661 Russian Federation. No. 2018138330 Bull. Number 16 (2019) 